\title{
Action Mechanism of Synthesized Nitrogen Base Analogues that inhibit Tomato Mosaic tobamovirus \\ Noha.K.El Dougdoug ${ }^{1}$, Hala.K.El Shahat ${ }^{1}$, M.M.Amer ${ }^{1}$, W.A.El Dougdoug ${ }^{2}$, K.A.El Dougdoug ${ }^{3}$ \\ ${ }^{1}$ Microbiology, and Botany, Dept., Faculty of Science, Benha Univ., Benha, Egypt \\ ${ }^{2}$ Chemistry, Dept., Faculty of Science, Benha Univ., Benha, Egypt \\ ${ }^{3}$ Microbiology, Dept., Faculty of Agriculture, Ain Shams Univ, Cairo, Egypt \\ E-mail:drdougdoug@yahoo.com
}

\begin{abstract}
:
Synthetic Nitrogen Base Analogues (SNBA) fused heterocyclic purine and pyrimidine derivatives are of great biological interest, especially as antiviral, antitumor and antimicrobial agents. The viruses are one of the risk factors for plants resulting in gigantic economic losses . Four SNBA compounds were assayed antiviral activity, plant cytotoxicity as well as determining their mode of action against Tomato mosaic tobamovirus (ToMV) by using the local lesion on Datura metel as well as infectivity assayed on tomato plants. The cytotoxicity of Ph-Oxanzolo and Oxazalone compounds at concentrations 15 and $20 \mu \mathrm{g} / \mathrm{mL}$ showed chlorosis, mottling, necrosis, wilting, and curling at three to four days after spraying while Hippuric acid and Benzotriazolo compounds were safe on test plants and didn't show any signs of toxicity on D.metel and tomato plants. Ph-Oxanzolon and Oxazalone had virucidal activity where showed high percentage of inhibition at simultaneous- ToMV inoculation at 5,10,15,20 ppm concentration and low percentage of inhibition at pre-and -post ToMV inoculation, as well as they showed high ToMV concentration and low percentage disease severity at $10 \mathrm{ppm}$ concentration. While another Hippuric acid and Benzotriazol had affect the ToMV replication process, where showed weak inhibitory activity of inhibition at simultaneous - ToMV inoculation at $5,10,15,20 \mathrm{ppm}$ concentration and low percentage of inhibition at pre-and-post ToMV inoculation , as well as they showed very low doubtful ToMV concentration and disease severity percentage at 15 ppm concentration .
\end{abstract}

Keywords: Antiviral, Mechanism of action, Nitrogen Base Analogues Synthetic Pyrimidine and purine derivatives, TMV.

\section{Introduction}

Plant virus diseases reduced every year approximately $15 \%$ of global yield of economically important crops $(9,18)$. Plant viruses are an obligate parasite in plant cells and characteristic the second largest culprits causing losses to various field crops worldwide, i.e., about 60 billion USD in financial terms (2). Tomato mosaic virus (ToMV) among the most hazardous plant viruses. It is a helical symmetry, positive sensed single stranded (+ss) RNA, classified to genus Tobamovirus and family Virgaviridae. It is producing symptoms like mosaic"- like mottling and discoloration on leaves. It causes loss of various crops including 125 plant species such as tobacco, cucumber, pepper and ornamentals (35). The plants have immune system $(19,20,29)$ but do not have the same animals immune system. To control plant virus disease appears to be extremely difficult, the virus is absolutely dependent on their hosts . Currently the development of efficient antiviral for elimination and prevention of attack by chemical synthesis has become the core area of research (14). Heterocyclic purine and pyrimidine structures are particularly versatile as it is possible to incorporate functional groups either as substituents or as part of the ring system itself or introduction of an additional ring to the purine and pyrimidines core tends to exert profound influence in conferring novel biological activities in these molecules $(3,13)$. Purine and pyrimidine compounds are widely distributed in nature for example nucleic acid bases (uracil, thymine, and cytosine) are derivatives of pyrimidine, Chlorophyll and thiamine (vitamin B1), riboflavin (vitamin B2), pyridoxol (vitamin B6), nicotinamide (vitamin B3) and ascorbic acid (vitamin C), and also of the twenty amino acids commonly found in proteins namely histidine, proline and tryptophan are heterocyclic pyrimidine compounds (6). An interest is aroused to the biologically active pyrimidine and fused heterocyclic pyrimidine nucleosides as potent antiviral agents against both human and plant viruses. In the field of plant virology concerning this issue we can find for example; 6-Azauracil caused a marked reduction in the number and size of local lesions on excised Nicotiana glutinosa leaves or leaf discs inoculated with tobacco mosaic virus or its nucleic acid (12), the pyrimidine analogues 2-thiouracil, 2-thiouridine, 6-azauracil and 6-azauridine all inhibited the synthesis of turnip yellow mosaic virus (TYMV) in infected Chinese cabbage leaf discs (24), Potato viruses have been eliminated in potato meristem culture by using 2,4-dioxohexahydrol,3,5-triazine (8), and inhibition the multiplication of tobacco mosaic virus and cowpea chlorotic mottle virus in disks from mechanically inoculated leaves by 2-thiopyrimidine and 2,4-dithio pyrimidine (11). The current study has been done to estimate the action mechanism of, the antiviral synthesized Nitrogen Base Analogues included pyrimidine and purine compounds against ToMV.

\section{Materials and Methods \\ Chemical compounds}

The four Synthesized Nitrogen Base Analogues (SNBA) under this investigation were synthesized by (34) Dept. of chemistry, faculty of science , Benha University, Egypt . 
- Hippuric acid $\left(\mathrm{C}_{9} \mathrm{H}_{9} \mathrm{NO}_{3}\right)$ :is white solid, soluble in hot water, (M. wt. $179.17 \mathrm{~g} \mid$ mole and M. P. 187 $\left.188^{\circ} \mathrm{C}\right)$

- Benzotriazole $\left(\mathrm{C}_{6} \mathrm{H}_{5} \mathrm{~N}_{3}\right)$ : is Pale yellow solid ,soluble in water, , (M. wt. $123.15 \mathrm{~g} \mid$ mole and M. P. $\left.99-100^{\circ} \mathrm{C}\right)$

- Hippuric-benzaldehyde azalactone $\left(\mathrm{C}_{16} \mathrm{H}_{11} \mathrm{NO}_{2}\right)$ is Pale yellow solid, soluble in water, (M. wt. $249.2640 \mathrm{~g} \mid$ mole and M. P. $157-159^{\circ} \mathrm{C}$ )

- 4-Hydroxy Oxazolone $\left(\mathrm{C}_{16} \mathrm{H}_{10} \mathrm{NO}_{3}\right)$ is yellow solid, soluble in water (M. wt. $2660.27 \mathrm{~g} \mid$ mole and M. P. $\left.165-167^{\circ} \mathrm{C}\right)$.

Preparation of synthetic compounds

The SNBA compounds were dissolved as $10 \mathrm{mg}$ each in $1 \mathrm{~mL}$ of $10 \%$ Dimethyl Sulfoxide (DMSO) in deionized water $(900 \mu \mathrm{L}$ de-ionized water and $100 \mu \mathrm{L}$ DMSO). Four concentrations of each compound were prepared as 5, 10, $15 \& 20$ ppm for bioassay.

Plant materials

Datura metel,L, Nicotiana tabacum cv white burly and Tomato, Solanum esculantum cv castle rock seeds were obtained from Virology Labs Department of Microbiology, Faculty of Agriculture , Ain Shams University . D. metel used as local lesion assay . N. tabacum cv white burly used as virus propagation and Tomato used for infectivity assay against ToMV .

2.4Source of the virus

Tomato mosaic tobamovirus (ToMV, strain U1) KA02 gene complete of coat protein, cds GenBank: LC515212.1 maintained as a local lesion on Datura metel leaves was kindly provided by ( 1 ) of Virology Labs , Faculty of Agriculture, Ain Shams Univ. .
Preparation of virus inoculum,

Local lesion of ToMV , strain on D. metel leaves were ground in phosphate buffer (pH 7) (1:2 w/v) using a pestle and mortar. The extraction was squeezed through four layers of muslin. removed by squeezing through four layers of muslin . The filtrate was mechanical inoculated N. tabacum cv white burly and kept in greenhouse condition. N. tabacum leaves showing systemic symptoms were ground in phosphate buffer ( $\mathrm{pH} 7)(1: 2 \mathrm{w} / \mathrm{v})$ using a pestle and mortar. The extraction was squeezed through four layers of muslin. . and centrifuged at 4,000 $\mathrm{g}$ for 15 min The supernatant (infectious sap) was kept at $20^{\circ} \mathrm{C}$ overnight to precipitate any proteinaceous virus inhibitor presented in leaf sap. The supernatant was further clarified by centrifugation at $3,000 \mathrm{~g}$ for $15 \mathrm{~min}$. The clarified virus inoculum were diluted with phosphate buffer ( $\mathrm{pH}$ 7) to give a suitable number of discrete local lesions on test plants (31).

Cytotoxicity test

The cytotoxicity and inhibition activity of SNBA compounds were examined on D. metal leaves and tomato plants. Seeds of D.metal L. and tomato cv castle rock were sown in $15 \mathrm{~cm}$ plastic pots $(5$ seeds /pot ) containing mixture of clay and sand under the Green house condition at Botanical garden Fac. of Science Benha University. Healthy test plants were sprayed with each SNBA at concentrations 5, 10, 15 and $20 \mathrm{ppm} / \mathrm{mL}$ and abnormal morphological changes in shape or color were recorded through three days after spraying

Table (1) Characteristics of Nitrogen Base Analogues under study.

\begin{tabular}{lccc}
\hline Name & Chemical formula \\
\hline Hippuric acid & $\mathrm{C}_{9} \mathrm{H}_{9} \mathrm{NO}_{3}$ \\
Benzotriazolo & $\mathrm{C}_{6} \mathrm{H}_{5} \mathrm{~N}_{3}$ \\
Hippuric-benzaldehyde & $\mathrm{C}_{16} \mathrm{H}_{11} \mathrm{NO}_{2}$ \\
azalactone &
\end{tabular}




\section{Local lesion assay}

Virus inhibited mechanism was studied for the Synthesized Nitrogen Base Analogues (SNBA) by three mode of inhibitions : virucidal activity, adsorption process and virus replication

Simultaneous-inoculation treatment was assayed by inoculated the mixture of ToMV and each compound $(1: 1 \mathrm{v} / \mathrm{v})$ ( incubated at room temperature for $1 \mathrm{hr}$ ) onto D.metal leaves. This treatment was applied to detect the compound has virucidal activity (act as virus inactivator) according to Modified from (26).

Pre-inoculation treatment was assayed sprayed the SNBA firstly on D.metal leaves and then after $24 \mathrm{hrs}$ inoculated with ToMV. This treatment was applied to detect the compound has affect the adsorption process (act as virus inhibitor) according to (36):.

Post-inoculation treatment was assayed by ToMV was inoculated on D.metal leaves and then after 24hrs sprayed with SNBA .This treatment was applied to detect the compound affect the virus replication (act as virus inhibitor) according to Modified from (5)

D.metal leaves were dusted with carborandum (600-mesh ) and inoculated with ToMV. by forefinger

In control plants, the leaves were inoculated with ToMV mixed with an equal volume of water (positive control),while D.metql leaves were inoculated only with the same volume of compound (negative control) .The development of local lesions were recorded through five days after inoculation. The percentage of inhibition was calculated according to (28):

Virus inhibition $=100-(\mathrm{A} / \mathrm{B} \times 100)$

where $(A)$ is the number of local lesions formed on treated leaves while (B) is the number of local lesions formed on control "untreated" leaves.

Infectivity assay: Seeds of Tomato, cv castle rock were sown in $25 \mathrm{~cm}$ plastic pots (5 seeds /pot) containing mixture of clay and sand under the Green house condition at Botanical garden Fac. of Science Benha University . Leaves were ready for inoculation after 15-20 days from planting. Virus inhibited mechanism was studied for SNBA compounds in three treatment: Healthy tomato leaves were sprayed with the SNBA compound Pre- ToMV inoculation at $24 \mathrm{hrs}$. This treatment was applied to detect whether the compound has affect the adsorption process (act as virus inhibitor) or not (36). Healthy tomato leaves were inoculated with ToMV and sprayed with the SNBA compound Post- ToMV inoculation at $24 \mathrm{hrs}$. This treatment was applied to detect the compound affect the virus replication (act as virus inhibitor) (5).

Determination of disease severity: The disease severity of each treated virus was determined using the following rating:

Scale: $0=$ no symptoms; $2=$ vein clearing; $4=$ mild mosaic; $6=$ severe mosaic; $8=$ leaf narrow and $10=$ leaf deformation . Disease severity (DS) values were calculated using the following formula according to (35).

$$
\text { DS }=\frac{\Sigma(\text { disease grade } \times \text { No. of plants in each grade })}{(\text { total No. of plants } \times \text { highest disease grade })} \times 100
$$

Determination of virus concentration : The serologically kits were obtained from Agric. Research Center (ARC) provided by (LOEWE Biochemica GmbH Germany) by double antibodies sandwich enzyme linked immunosurbant assay (DAS ELISA) according to (10) .The virus concentration was determined to each treatment were monitored using ELISA reader at $405 \mathrm{~nm}$.

\section{Statistical analysis}

All plant chemical analysis data were statistically analyzed using Two-way ANOVA and Holm-Sidak test (SigmaPlot 12.0) at 0.05 level of probability. The values recorded in the values of the biochemical analysis are means of three replicates.

\section{Results}

The current study has been done to estimate the antiviral activity of four Synthesized Nitrogen Base Analogues belonging to the fused heterocyclic pyrimidine and purine groups, effective and promising compounds against ToMV, as well as their mechanism of action.

\section{Antiviral selection}

Cytotoxicity of Antiviral compounds:

The plant cytotoxicity of four Synthesized Nitrogen Base Analogues (SNBA) was carried firstly to select the antiviral compounds that they were safe on D.metel and tomato plants (fig. 1).and The PhOxanzolon and Oxazalone compounds at concentrations 15 and $20 \mu \mathrm{g} / \mathrm{mL}$ were observed abnormal morphological changes in shape and color such as chlorosis, mottling, necrosis, wilting, and curling that occurs to D.matal plants for about three to four days after spraying . The results of cytotoxicity test indicated that all tested concentrations for each Hippuric acid and Benzotriazol compounds were safe on test plants and didn't show any signs of toxicity on D.metel and tomato plants.

Selection of Antiviral compound and concentration

Local lesion, number and variability (Smal to large irregular, Necrotic to chlorotic L.L .with to without center , . surrounded by necrotic ring or brown halo or surrounded by Chlorotic), (table $1 \&$ fig.2) against ToMV was observed that potential of SNBA compounds compared to native virus without tested compounds. The local lesions ToMV that were formed on D.metal plants were clearly showed in Fig. (2).The results revealed that the inhibitory activity of ToMV by $\mathrm{Ph}-$ Oxanzolon $54.4,62.0,73.7 \& 80.6 \%$ and

Oxazalone $48.6,72.6,74.0 \& 82.9 \%$ were higher than Hippuric acid $12.8,21.9,37.6 \& 43.5 \%$ and Benzotriazol 7.5 , 24.3, 36,8 \& $44.5 \%$ at $5,10,15 \&$ $20 \mathrm{ppm}$ concentrations respectively against ToMV . The reduction of ToMV infection was significance among between compounds SNBA.The results of ToMV inhibition indicated that $\mathrm{Ph}-\mathrm{Oxanzolon}$ and Oxazalone compounds were act with the ToMV as a virucidal activity. This may be due to the direct binding 
between the virus particles. The results in the formation of virus-inhibitor complex (i. e., the chemical configuration of this compound contains certain heterocyclic moieties which may alter virus capsid proteins) so the effect of compound here appears to be on the virus itself. In this case, it was described as virus inactivator .

The potency of antiviral activity of the selected concentrations (15 ppm) of Hippuric acid ,
Benzotriazolo, and (10 ppm) of Ph-Oxanzolon and Oxazalone against ToMV . To study the mechanism of action as virucidal activity or affect virus adsorption and attachment process or they may inhibit virus replication in some way done by three categories ; Simultaneous , Pre- and Post-inoculation treatments and applied using Local lesion and virus infectivity assays .

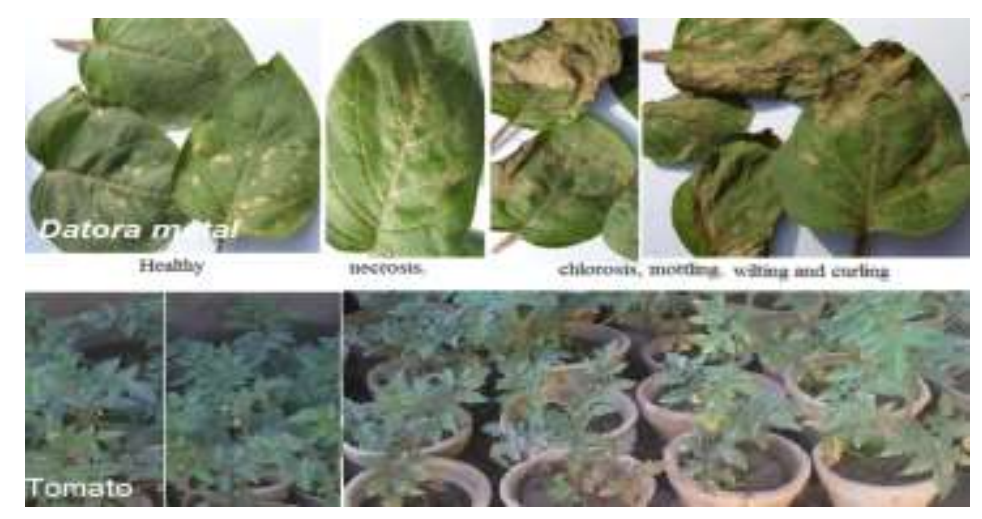

Fig. (1) Photo plate of D. metal and tomato plants showing the cytotoxicity such as chlorosis, mottling, necrosis, wilting , yellow and curling sprayed with four nitrogen bases analogues .

Table (1) Effect of simultaneous-treatment with nitrogen bases analogues on subsequent local lesions production by ToMV infection on D. metel leaves at different concentrations .

\begin{tabular}{|c|c|c|c|c|c|}
\hline Compounds & Conc. & $\begin{array}{l}\text { Mean } \\
\text { No,of LL }\end{array}$ & $\begin{array}{l}\% \text { of } \\
\text { inhibition }\end{array}$ & $\begin{array}{l}\text { Morphological } \\
\text { l..L characters }\end{array}$ & Cytotoxicity \\
\hline \multirow[t]{4}{*}{ Hippuric acid } & $5 \mathrm{ppm}$ & 65.4 & 12.8 & large irregular chlorotic L.L. & \multirow{3}{*}{$\begin{array}{l}\text { curling, yellow, } \\
\text { chlorosis, mottling, } \\
\text { yellow mottling , } \\
\text { necrosis, wilting }\end{array}$} \\
\hline & $10 \mathrm{ppm}$ & 58.6 & 21.9 & large irregular chlorotic L.L & \\
\hline & $15 \mathrm{ppm}$ & 46.8 & 37.6 & $\begin{array}{l}\text { Medium irregular chlorotic } \\
\text { L.L.with center }\end{array}$ & \\
\hline & 20ppm & 42.4 & 43.5 & $\begin{array}{l}\text { Small irregular chlorotic } \\
\text { L.L.with center }\end{array}$ & $\begin{array}{l}\text { Irregular ,spotted } \\
\text { mottling, brawn necrosis. }\end{array}$ \\
\hline \multirow[t]{4}{*}{ Benzotriazol } & $5 \mathrm{ppm}$ & 69.4 & 7.5 & $\begin{array}{l}\text { Necrotic L.L. surrounded by } \\
\text { necrotic ring }\end{array}$ & No .toxicity \\
\hline & $10 \mathrm{ppm}$ & 56.8 & 24.3 & Chlorotic L.L. & \multirow{2}{*}{$\begin{array}{l}\text { No .toxicity } \\
\text { No .toxicity }\end{array}$} \\
\hline & $15 \mathrm{ppm}$ & 47.4 & 36,8 & $\begin{array}{l}\text { Irregular chlorotic L.L. and } \\
\text { surrounded with brown halo }\end{array}$ & \\
\hline & 20ppm & 41.6 & 44.5 & $\begin{array}{l}\text { Irregular chlorotic L.L. and } \\
\text { surrounded with brown halo }\end{array}$ & No .toxicity \\
\hline \multirow[t]{4}{*}{ Ph-Oxanzolon } & $5 \mathrm{ppm}$ & 34.2 & 54.4 & Necrotic L.L. without halo & \multirow{2}{*}{$\begin{array}{l}\text { No .toxicity } \\
\text { No .toxicity }\end{array}$} \\
\hline & $10 \mathrm{ppm}$ & 28.5 & 62.0 & $\begin{array}{l}\text { Ring necrotic } \\
\text { surrounded with } \\
\text { halo }\end{array}$ & \\
\hline & $15 \mathrm{ppm}$ & 19.7 & 73.7 & 1- Necrotic ring., & \multirow{4}{*}{$\begin{array}{l}\text { No .toxicity } \\
\text { No .toxicity } \\
\text { curling, mottling, } \\
\text { necrosis, wilting } \\
\text {, yellow, chlorosis, } \\
\text { necrosis, wilting }\end{array}$} \\
\hline & $20 \mathrm{ppm}$ & 14.5 & 80.6 & Chlorotic L.L. & \\
\hline \multirow[t]{4}{*}{ Oxazalone } & $5 \mathrm{ppm}$ & 38.5 & 48.6 & $\begin{array}{l}\text { Irregular chlorotic L.L. and } \\
\text { surrounded with brown halo }\end{array}$ & \\
\hline & 10ppm & 20.5 & 72.6 & $\begin{array}{l}\text { Irregular chlorotic L.L. and } \\
\text { surrounded with brown halo }\end{array}$ & \\
\hline & $15 \mathrm{ppm}$ & 19.5 & 74.0 & Necrotic L.L. without halo & \multirow{2}{*}{$\begin{array}{l}\text { yellow, chlorosis, } \\
\text { wilting } \\
\text { yellow mottling, } \\
\text { necrosis, wilting }\end{array}$} \\
\hline & 20ppm & 12.8 & 82.9 & $\begin{array}{l}\text { Small Necrotic L.L. } \\
\text { surrounded by Chlorotic }\end{array}$ & \\
\hline Positive control & -- & 75 & -- & $\begin{array}{l}\text { Small Necrotic L.L. } \\
\text { surrounded by Chlorotic }\end{array}$ & No .toxicity \\
\hline
\end{tabular}




\section{Virus inhibition}

The results in Table (2) showed that only Hippuric acid and Benzotriazolo at $15 \mathrm{ppm}$ concentration showed lowest inhibition effect giving $37.6 \& 36,8 \%$ inhibition respectively against ToMV . On the other hand Ph-Oxanzolon and Oxazalone at 10 ppm concentration had strong virucidal effect giving $62.0 \& 72.6 \%$ inhibition respectively against ToMV .

The pre- ToMV inoculation treatment revealed that sprayed D. metal with Hippuric acid and Benzotriazol at $15 \mathrm{ppm}$ concentration showed highest inhibition effect giving $\mathbf{6 4 . 5} \& \mathbf{7 0 . 9} \%$ inhibition respectively against ToMV . On the other hand, $\mathrm{Ph}$ Oxanzolon and Oxazalone at $10 \mathrm{ppm}$ concentration had lowest inhibition effect giving 21.7\& $20.8 \%$ inhibition respectively against ToMV . This suggested that these Hippuric acid and Benzotriazolo at $15 \mathrm{ppm}$ concentration inhibited ToMV replication

The post - ToMV inoculation treatment was clear that compounds, Hippuric acid and Benzotriazolo at 15 ppm concentration showed highest inhibition effect giving $83.5 \& \mathbf{7 7 . 9} \%$ inhibition respectively against ToMV . It had effect inhibition in replication may acts as a nucleoside analogue that interfere in the replicative cycle of the virus for example, by being incorporated in place of the natural nucleoside or by inactivation of the viral RNA polymerase complex in some way affecting transcription and replication processes of viral genome . On the other hand, Ph-Oxanzolon and Oxazalone at $10 \mathrm{ppm}$ concentration had weakest inhibition effect giving $20.9 \& \mathbf{1 9 . 3} \%$ inhibition respectively against ToMV . It had no effect on the replication process of ToMV inside the plants (gave no significant \% of virus inhibition).

Virus pathogenesis :

Sprayed infected tomato plant with selected Hippuric acid , Benzotriazolo , (15 ppm) and PhOxanzolo and Oxazalone $(10 \mathrm{ppm})$ pre-and post ToMV inoculation due to reduction of ToMV infectivity. Such as reduction of symptoms, showed mild mosaic (fig. 2) and ToMV concentration Table (2)
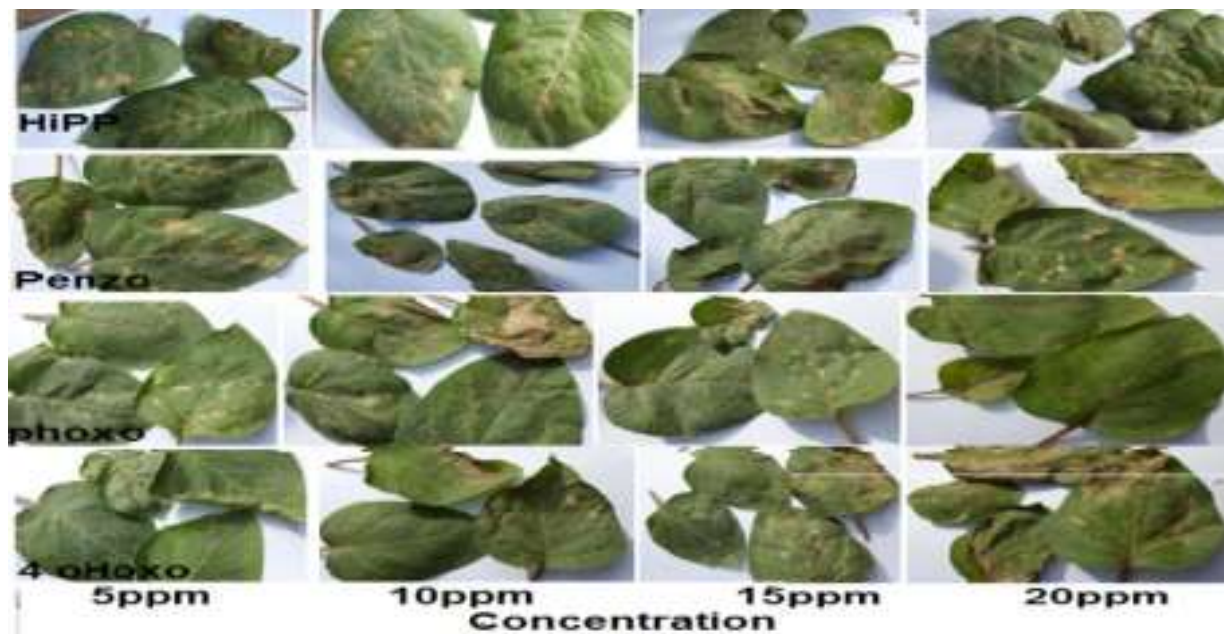

Fig. (2) Photo plate showing D.metal leaves simultaneous-treatment with nitrogen base analogues compounds at different concentration on subsequent local lesions produced by Tomato mosaic virus.

Table (2) Effect of simultaneous, pre and post treatments with nitrogen bases analogues on subsequent local lesions production by ToMV inoculated D. metal leaves at different concentrations.

\begin{tabular}{|c|c|c|c|c|c|c|}
\hline \multirow{2}{*}{$\begin{array}{c}\text { Treatments } \\
\text { Compound conc. }\end{array}$} & \multicolumn{2}{|c|}{ Simultaneous-treatment } & \multicolumn{2}{|c|}{ Pre-treatment } & \multicolumn{2}{|c|}{ post-treatment } \\
\hline & $\begin{array}{c}\text { Mean No. of } \\
\text { L.L. }\end{array}$ & $\begin{array}{c}\% \text { Virus } \\
\text { inhibition }\end{array}$ & $\begin{array}{c}\text { Mean No. } \\
\text { of L.L. }\end{array}$ & $\begin{array}{c}\% \text { Virus } \\
\text { inhibition }\end{array}$ & $\begin{array}{c}\text { Mean No. } \\
\text { of L.L. }\end{array}$ & $\begin{array}{c}\% \text { Virus } \\
\text { inhibition }\end{array}$ \\
\hline Control & 70 & ---- & 70 & ---- & 70 & ---- \\
\hline $\begin{array}{l}\text { Hippuric acid } \\
\text { (15 ppm) }\end{array}$ & 46.8 & 37.6 & 26.6 & 64.5 & 12.4 & 83.5 \\
\hline $\begin{array}{l}\text { Benzotriazol } \\
\text { (15 ppm) }\end{array}$ & 47.4 & 36,8 & 21,8 & 70.9 & 16,6 & 77.9 \\
\hline $\begin{array}{l}\text { Ph-Oxanzolon } \\
\text { (10 ppm) }\end{array}$ & 28.5 & 62.0 & 58.7 & 21.7 & 59.3 & 20.9 \\
\hline $\begin{array}{l}\text { Oxazalone } \\
\text { (10 ppm) }\end{array}$ & 20.5 & 72.6 & 59.4 & 20.8 & 60.5 & 19.3 \\
\hline
\end{tabular}


Table (2) Disease severity and Virus concentration of ToMV infected tomato plants sprayed with nitrogen bases analogues (In vivo).

\begin{tabular}{|c|c|c|c|c|c|c|c|c|c|}
\hline \multirow{2}{*}{\multicolumn{2}{|c|}{ Parameters }} & \multicolumn{4}{|c|}{ Symptoms index } & \multicolumn{3}{|c|}{ Virus infectivity } & \multirow{2}{*}{$\begin{array}{c}\text { Virus } \\
\text { concentration } \\
\text { (Optical density } \\
\text { at } 405 \mathrm{~nm})^{* *}\end{array}$} \\
\hline & & $\begin{array}{c}\text { No } \cdot \text { of } \\
\text { infected } \\
\text { plants }\end{array}$ & $\begin{array}{l}\mathbf{m M} \\
*(4)\end{array}$ & $\begin{array}{c}\text { SM } \\
*(6)\end{array}$ & $\begin{array}{l}\text { Def. } \\
*(8)\end{array}$ & $\begin{array}{c}\% \\
\text { Inf. }\end{array}$ & $\begin{array}{c}\% \\
\text { Red. }\end{array}$ & $\begin{array}{c}\% \\
\text { Disease } \\
\text { severity } \\
\end{array}$ & \\
\hline \multicolumn{2}{|c|}{ Infected plant Control } & 9 & 0 & 2 & 7 & 90 & - & 85.0 & 0.425 \\
\hline Pre- & Hippuric acid & 2 & 2 & 1 & 0 & 22.2 & 75.3 & 17.5 & 0.262 \\
\hline infected & Benzotriazol & 2 & 2 & 1 & 0 & 22.2 & 75.3 & 17.5 & 0.259 \\
\hline \multirow{2}{*}{ plant } & Ph-Oxanzolon & 5 & 2 & 3 & 0 & 55.5 & 38.3 & 32,5 & 0.316 \\
\hline & Oxazalone & 5 & 3 & 2 & 0 & 55.5 & 38.3 & 30.0 & 0.325 \\
\hline \multirow{4}{*}{$\begin{array}{l}\text { Post } \\
\text { infected } \\
\text { plant }\end{array}$} & - Hippuric acid & 4 & 2 & 1 & 1 & 44.4 & 50.7 & 27.5 & 0.287 \\
\hline & Benzotriazol & 4 & 3 & 1 & 0 & 44.4 & 50.7 & 22.5 & 0.297 \\
\hline & Ph-Oxanzolon & 6 & 2 & 2 & 2 & 66.6 & 26.0 & 45 & 0.375 \\
\hline & Oxazalone & 6 & 2 & 3 & 1 & 66.6 & 26.0 & 42.5 & 0.357 \\
\hline
\end{tabular}

Total inoculated plants $=90$ plant, $\%$ Inf $=\%$ Infection $2 \& 3) \quad 90 \%$ Infection , $85.0 \%$ Disease severity and , $\%$ Red $=\%$ Reduction .

* Degree of Symptoms index (4) mM=mild mosaic ),

(6) $\mathrm{sM}=$ sever mosaic) ,

(8) Def. = deformation) .

**Virus concentration was determined at the means of three replicates by DAS ELISA .

OD $405 \mathrm{~nm}$, Negative $=0.125$, Positive $=0.521$

The results of ToMV infectivity revealed that Hippuric acid and Benzotriazolo high reduction of ToMV infectivity, while Ph-Oxanzolon and Oxazalone was low reduction of ToMV infectivity as pre-and post ToMV inoculation. The reduction of percent infection at pre--infected plant were $60,60,50,50$ $\%$ as well as disease severity were $20,17.1,27.5$; $27.5 \%$ and post-infected plant due to low reduction with 40.30, 50,50 as well as disease severity 22.5 , $17.1,30.0,35.0 \%$ respectively at 45 days plant growth . Comparing to no sprayed ToMV infected tomato plants with $90 \%$ ToMV infectivity and $85 \%$ disease severity . Hippuric acid and Benzotriazol showed was high reduction by $75.3 \& 75.3$ pre- and $50.7 \& 50.7$ post and low of ToMV concentration by $0.262 \&, 0.262$ pre- and $0.287 \& 0.297$ OD post respectively. While Ph-Oxanzolon and Oxazalone were recorded low reduction by $38.3 \& 38.3$ pre- and $26.0 \& 26.0$ post respectively and high of ToMV concentration by $0.316 \&, 0.325$ pre- and $0.375 \& 0.357$ OD post respectively (table, 2) . Compared plant control showed sever mosaic, and deformation ( fig.

0.425 OD ToMV concentration (Table $2 \&$ fig. 3 ) . The study further details concerning their mechanism of action . According to virus infectivity and concentration Ph-Oxanzolon and Oxazalone affect the adsorption process, while Hippuric acid and Benzotriazolo may inhibit virus replication .

The results in Table 2 revealed that pre-and post inoculation treatment with both $\mathrm{Ph}-\mathrm{Oxanzolon}$ and Oxazalone compounds was not effective against virus (gave the weakest \% of virus inhibition). This suggested that these compounds had effect on the attachment process of the virus to the infective sites (i. e., can't prevent the entry of virus into plant cells). Hippuric acid and Benzotriazolo revealed that preand post inoculation treatment was effective against virus (gave the highest $\%$ of virus inhibition). This suggested that these compounds had no effect on the attachment process of the virus to the infective sites (i. e., can't prevent the entry of virus into plant cells). had effect on the replication process of virus inside the plants (gave no significant $\%$ of virus inhibition) .The inhibition in replication showed by Hippuric acid and Benzotriazol compounds might be either due to it may acts as a nucleoside analogue that interfere in the replicative cycle of the virus for example, by being incorporated in place of the natural nucleoside or by inactivation of the viral RNA polymerase complex in some way affecting transcription and replication processes of viral genome.

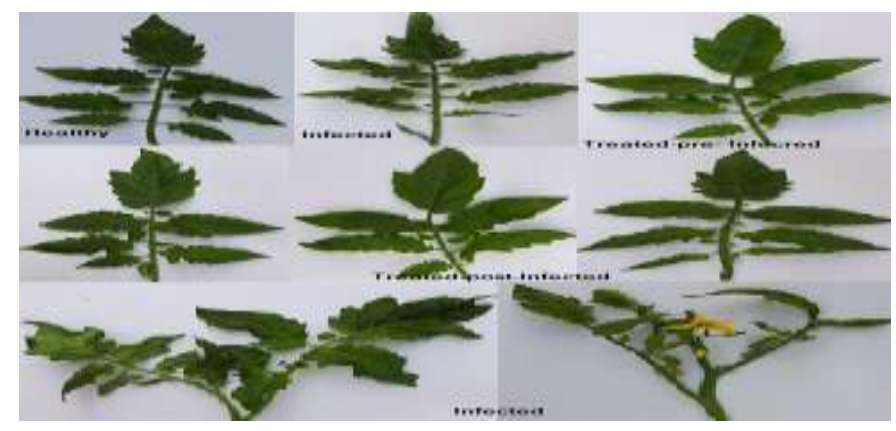

Fig.(3) Tomato leaves pre and post -treatment with nitrogen base analogues (HiPP) compound on subsequent systemic infection symptoms produced by Tomato mosaic virus, 


\section{Discussion}

The current study was evaluated novel anti- ToMV inhibitors using Synthesized Nitrogen Base Analogues heterocyclic purine and pyrimidine nucleosides as potent antiviral agents. The obtained result of plant cytotoxicity of four Synthesized Nitrogen Base Analogues (SNBA) on D.metel and tomato plants showed that, Ph-Oxanzolon and Oxazalone compounds at concentrations 15 and $20 \mu \mathrm{g} / \mathrm{mL}$ were observed abnormal morphological changes in shape and color while Hippuric acid and Benzotriazol didn't showed any signs of toxicity at about 3 to 4 days after spraying. These result agreement with some several searches work on Nitrogen Base Analogues such as , 0.005M concentrations of the guanine analogue ( guanazolo) caused negligible plant damage, but at higher concentrations produced a slight yellowing and distortion in the younger leaves with stunting were prolonged, [22] . No cytotoxicity effect was recorded with both purine and pyrimidine analogues on Sunflower [17] . The cytotoxicity test of novel fused thiophene and thienopyrimidine derivatives showed safe on MDCK cells using MTT assay in vitro [25]. Synthetic Fused Heterocyclic Pyrimidines were safe on Phaseolus vulgar and Datura metel at concentrations 10 and $20 \mu \mathrm{g} / \mathrm{mL}$, [23].

Resently many new researches studied the biologically active derivate fused heterocyclic pyrimidine nucleosides and as potent antiviral agents and their mechanism of action. In the current study selection concentration of four Synthesized Nitrogen Base Analogues belonging to the fused heterocyclic purine and pyrimidines nucleosides against ToMV has been done to estimate the antiviral effect (s) as well as their mechanism of action.

Local lesion assay is the most widely accepted method for determining the percentage inhibition of plant virus. The results of antiviral selected concentration showed that $10 \mathrm{ppm}$ of Ph-Oxanzolon and Oxazalone and $15 \mathrm{ppm}$ at concentrations Hippuric acid and Benzotriazolo were observed normal morphological in shape and color on D.metal and tomato plants as well as showed high percentage of inhibition at concentration. This result revealed also that the inhibitory activity of Ph-Oxanzolon and Oxazalone were higher than Hippuric acid and Benzotriazol compounds showed weak inhibitory activity at same concentration.. Another observation the data was that; TMV was more affected by the inhibitory activity of tested compounds where the rod shaped TMV has a larger surface area subjected to the compounds.

Two compounds Ph-Oxanzolon and Oxazalone had virucidal activity where showed high percentage of inhibition at simultaneous- ToMV inoculation at $5,10,15,20$ ppm concentration and low percentage of inhibition at pre-and -post ToMV inoculation , as well as they showed high ToMV concentration and low percentage disease severity at $10 \mathrm{ppm}$ concentration The potency of antiviral activity of the two selected $\mathrm{Ph}$ Oxanzolon and Oxazalone compounds at $10 \mathrm{ppm}$ concentrations against ToMV leads us to study further details concerning their mechanism of action have virucidal activity or they affect the adsorption process or they may inhibit virus replication in some way. Plant virus inhibited mechanism was studied for the most potent chemical compounds in three categories; Preinoculation treatment. Post-inoculation treatment and Simultaneous-inoculation treatment.

While another two compounds Hippuric acid and Benzotriazol had affect the ToMV replication process, where showed weak inhibitory activity of inhibition at simultaneous- ToMV inoculation at 5,10,15,20 ppm concentration and low percentage of inhibition at preand-post ToMV inoculation, as well as they showed very low doubtful ToMV concentration and disease severity percentage at $15 \mathrm{ppm}$ concentration .

The results revealed that Hippuric acid and Benzotriazol compounds was effective against ToMV (gave the weakest \% of virus inhibition). This suggested that these compounds had no any effect on the attachment process of the virus to the infective sites (i. e., can't prevent the entry of virus into plant cells). From the results it was clear that compound had effect on the replication process of both viruses inside the plants (gave significant percentage of virus inhibition) . However, only compound showed strong percentage of virus inhibition, might be either due to it may acts as a nucleoside analogue that interfere in the replicative cycle of the virus for example, by being incorporated in place of the natural nucleoside or by inactivation of the viral RNA polymerase complex in some way affecting transcription and replication processes of viral genome. During evaluation the virucidal effect of both compounds by subjecting virus to the compounds directly.

Concerning the antiviral activity of Synthesized Nitrogen Base Analogues, several researchers have been reported the effectiveness of synthetic Synthesized Nitrogen Base Analogues compounds in inhibiting plant ,animal and human viruses. For examples, Only two compounds (1\&8) out of eight fused heterocyclic pyrimidines compounds showed significant percentage of inhibition tobacco mosaic virus (TMV) and tobacco necrosis virus (TNV) viruses at concentration $20 \mu \mathrm{g} / \mathrm{ml}$ while the remaining six compounds $(2,3,4,5,6, \& 7)$ showed weak inhibitory activity at same concentration. Mechanism of action studies on both potent compounds revealed that compound number [1] had virucidal activity against both TMV and TNV while compound number [8] seemed to affect the replication process of both viruses [23]. The guanine analogue, 8-azaguanine, had a marked inhibitory effect on lucerne mosaic (LMV) and cucumber mosaic viruses (CMV) but had much less effect on disease development with TMV by [22], the inhibitory action of halogenated pyrimidines such as 5-fluoruoridine, and 2-thio-5-fluorouracil on the formation of TMV in isolated leaf disks of Turkish tobacco plants by [30], the effectiveness of both purine and pyrimidine analogues on the infectivity of Sunflower mosaic virus in vitro and in vivo by [17], the 
antiviral activity of novel thiourea containing chiral phosphonate on Tobacco Mosaic Virus by [14]. [33] found that the newly synthesized 2-substituted methylthio- 5-(4-amino-2-methylpyrimidin-5-yl-)-1,3,4oxadiazole derivatives exhibited a potent antiviral against TMV in vivo, a series of pyrazolo[3,4-d] pyrimidine derivatives containing a schiff base moiety exhibited significant activity against TMV by [32], the 4-[(1,2-dihydro-2-oxo- 3H-indol-3-ylidene)amino]-N(4,6-dimethyl- 2-pyrimidin-2-yl) benzene-s ulphonamide and its derivatives showed antiviral potencies (90\% inhibition) against influenza A (H1N1, $\mathrm{H} 3 \mathrm{~N} 2$, and $\mathrm{H} 5 \mathrm{~N} 1$ ) and $\mathrm{B}$ viruses in MDCK cell culture by [27] and the anti-HSV-1 activity of some new synthesized substituted pyrimidine, thiopyrimidine and thiazolopyrimidine derivatives by [21].

Bawden [7] found that the inhibitors of plant virus increase include pyrimidine, purine analogues 2thiouracil, and 8-azaguanine inhibits virus multiplication by affecting some host-cell mechanism. [30] found that the inhibition of TMV formation and the incorporation of 5-fluorouracil into viral RNA occurs in Phlox drummondi as well as in the Turkish tobacco host. The inhibitory action of 5-fluorouracil on the formation of TMV in isolated leaf disks of Turkish tobacco plants is dependent on the time interval which has elapsed between infection and exposure to 5fluorouracil, [15] found that from their experiments on time of application; the methyl benzimidazol-2ylcarbamate inhibits tobacco mosaic virus ribonucleic acid synthesis indirectly, by maintaining the host "tobacco plants" in a state unsuitable for viral multiplication, another research for [17] found that foliar sprays of test plant with some purine and pyrimidine analogues at 500ppm an hour after inoculation of sunflower mosaic virus rendered 91.90$100 \%$ virus incapable of initiating infection. Same results were obtained for human viruses on these types of chemical compounds; a series of pyrazinecarboxamide derivatives were found to inhibits the influenza viral RNA-dependent RNA polymerase by [16[. Similarly,. [14] found in his study that the mechanism of action of novel thiourea containing chiral phosphonate on Tobacco mosaic virus was by inhibiting the polymerization process of TMV capsid protein in vitro, also [32] found that pyrazolo [3,4-d] pyrimidine derivatives containing a schiff base moiety had a strong antiviral activity against TMV because this moiety displayed strong binding capability to TMV capsid "coat" protein.

\section{Conclusion}

From the current study, two new synthesized Nitrogen Base Analogues compounds belonging to the fused heterocyclic purne and pyrimidines with potent anti-TMV virus activity have been identified; $\mathrm{Ph}$ Oxanzolon and Oxazalone had virucidal activity. Hippuric acid and Benzotriazol were able to inhibit viruses replication (act as virus inhibitor) without damaging or affecting the host cells of plant. A future goal will be concerned with the chemical modification in the structure "design" of these new antiviral compounds by changing or insertion of one or more functional groups to either the pyrimidine and purine nucleus or its side chain to improve "increase" their inhibitory activity and make them able to target various stages in the plant viral life cycle which would avoid eliciting drug resistance.

\section{References}

[1] A.H.Abdelmoamen, K.Noha El-Dougdoug, A.M.El-Brolossy and K.A.El-Dougdoug , Serological and molecular characteristics of Tomato mosaic tobamoviruscoat protein gene.Arab Univ.,J.Agric.Sci.,Ain shams Univ.,Cairo. Special Issue.vol.26,pp.16131626,2018.

[2] K.O. Afolabi, B.C.Iweriebor, A.I.O koh, L.C.O bi, Global status of porcine circovirus type 2 and its associated diseases in sub-saharan Africa, Advances in Virology.vol.1,pp.1-16,2017.

[3] L. A.Agrofoglio, I.illaizeau, Y.Saito, Synthesis of some novel hydrazono acyclic nucleoside analogues. Chemical Reviews.vol.13,pp. 1875,2003 .

[4] R.AlfaroukOmar, A.B.Barakat Shoman, A.Sahar Ali, M.A.Rashad, Screening of some synthetic fused heterocyclic pyrimidines for anti-avian influenza virus (H5N1) activity. Egyptian Academic Journal of Biological Sciences.vol.1,pp.25- 33,2013.

[5] M.Amoros, E.Lurton, J.Boustie, L.Girre, Comparison of the antiherpes simplex virus activities of propolis and 3-methyl-But-2Enyl cafferate. Journal of Natural Products.vol.57,pp.644- 647,1994.

[6] W.L.F .Armarego, In: "The Chemistry of Heterocyclic Compounds, Fused Pyrimidines, Part I: Quinazolines", Brown, D.J. (Ed.), Vol. 24/1,Interscience Publishers.vol.12,pp.,1967.

[7] F.C.Bawden, Inhibitors and Plant Viruses. Advances in Virus Research.vol.2,pp.3157,1954 .

[8] S.Borissensko, G.Schuster, W.Schmygla, Obtaining a high percentage of explants with negative serological reactions against viruses by combining potato meristem culture with phytoviral chemotherapy. Phytopathology Z.vol.114,pp.185-188,1985.

[9] R.Cerda, J.Avelino, C.Gary, P.Tixier,E.Lechevallier, C.Allinne, Primary and secondary yield losses caused by pests and diseases: Assessment and modeling in coffee. PloS One.vol.12,pp.133-169,2017.

[10] M.F.Clark, and A.N.Adams, Characteristics of the microplate method of enzyme-linked immunosorbent assay for the detection of plant viruses. J. Gen. Virol.vol.34,pp.475-483,1977.

[11] W.O.Dawson, C.Boyd, Modifications of nucleic acid precursors that inhibit plant virus 
multiplication. Phytopathology.vol.77,pp.477480,1987.

[12] J.Dijkstra, J.J.S.Van Rensen, Effect of 6azauracil on infection with tobacco mosaic virus. Netherlands Journal of Plant Pathology.vol.74,pp.193-201,1968.

[13] A.B.A. El-Gazzar, H.N. Hafez, A.A. AbuHashem, A.S. Aly, Synthesis and antioxidant, anti-inflammatory, and analgesic activity of novel polycyclic pyrimido[4,5-b]quinolines. Phosphorus, Sulfur and Silicon and the Related Elements.vol.184,pp.379-405,2009.

[14] H.Fan , B.Song , P.S.Bhadury, L.Jin, D.Hu, S.Yang, Antiviral activity and mechanism of action of novel thiourea containing chiral phosphonate on Tobacco Mosaic virus. International Journal of Molecular Sciences.vol.5,pp.22-35,2011.

[15] R.S.S.Fraser, R.J.Whenham, Chemotherapy of plant virus disease with methyl benzimidazol2yl-carbamate: effects on plant growth and multiplication of tobacco mosaic virus. Physiological Plant Pathology.vol.13,pp.51$64,1978$.

[16] Y.Furuta, K.Takahashi, K.Shiraki, K.Sakamoto , J.Morrey, T-705 (favipiravir) and related compounds: Novel broad-spectrum inhibitors of RNA viral infections. Antiviral Research.vol.82,pp.95-102,2009.

[17] K.C.Gupta, A.N. Roy, Effect of purine and pyrimidine compounds on the infectivity of Sunflower Mosaic virus in vitro and in vivo. Proceedings of the Indian National Science Academy. Part B. Biological Sciences.vol.16,pp.912-941.1981.

[18] W.Islam, M.Zaynab, M.Qasim, Z.Wu, Plantvirus interactions: Disease resistance in focus. Hosts Viruses.vol.4,pp.5-20,2017.

[19] J.D.G.Jones, and J.L.Dang, Review The plant immune system. Nature.vol.44,pp.323$329,2006$.

[20] F.Katagiri , and K.Tsuda, CURRENT REVIEW , Understanding the Plant Immune System. MPMI Vol.23,pp.1050-1094,2010.

[21] S.F.Mohamed M.Flefel, E.A.Eman Abd ElGalil, A,El-Shafy, N.Dina, Anti-HSV-1 activity and mechanism of action of some new synthesized substituted pyrimidine, thiopyrimidine and thiazolopyrimidine derivatives. European Journal of Medicinal Chemistry.vol.45,pp.1494-1501,2010.

[22] R.E.F.Matthews, Chemotherapy and Plant Viruses. Journal of General Microbiology .vol.8,pp.277-288,1953.

[23] O.A.Rabiee, Screening the Antiviral Activity and Mode of Action of Some Synthetic Fused Heterocyclic Pyrimidines against Tobacco Mosaic Virus (TMV) \& Tobacco Necrosis Virus (TNV). Egypt. J. Bot .Vol.60,pp.549-561,2020.
[24] R.K. Ralph, S.J.Wojcik, Inhibition of turnip yellow mosaic virus synthesis by pyrimidine analogues. Biochimica et Biophysica Acta .vol.44, pp. 261-268,1976.

[25] A.E.Rashad, A.H.Shamroukh, R.E.AbdelMegeid, A.Mostafa, R.El-Shesheny, A.Kandeil, M. A.Ali, K.Banert, Synthesis and screening of some novel fused thiophene and thienopyrimidine derivatives for anti-avian influenza virus (H5N1) activity. European Journal of Medicinal Chemistry.vol.45,pp.52515257,2010 .

[26] A.Schuhmacher, J.Reichling, P.Schnitzler, () Virucidal effect of peppermint oil on the enveloped viruses herpes simplex virus type 1 and type 2 in vitro. Phytomedicine.6.vol,pp.504510.2003.

[27] P.Selvam , M.Narayanan, C.Markandavel, W.Robert, K.Wandersee, F.Donald, Antiinfluenza virus activities of 4-[(1,2-dihydro2- oxo- 3H-indol-3-ylidene)amino]-N-(4,6dimethyl- 2-pyrimidin- 2-yl) benzenesulphonamide and its. derivatives. Antiviral Chemistry \& Chemotherapy. vol. 17,pp. 269-274, ,2006.

[28] M.M.Smookler, Properties of inhibitors of plants virus infection occurring in leaves of species in chenopodiales. Annals of Applied Biology.vol.69,pp.157-168,1971.

[29] S.H.Spoel, and X.Dong, () . How do plants achieve immunity? Defence without specialized immune cells Nature Review Immunology ..vol.3,pp.12-89.2012.

[30] M.Staehelin, M.P.Gordon, () Effects of halogenated pyrimidines on the growth of tobacco mosaic virus. Biochimica et Biophysica Acta, 38,307-315,1960.

[31] R.Velazhahan , P.Narayanasamy, Inhibition of tomato spotted wilt virus (TSWV) by plant extracts. Science and Culture.vol.57,pp.141142,1991 .

[32] Wang, Yan-Yan, Fang-Zhou, Xu, Yun-Ying, Zhu, Baoan, Song, Shunhong, Chen. Pyrazolo[3,4-d] pyrimidine derivatives containing a Schiff base moiety as potential antiviral agents. Bioorganic \& Medicinal Chemistry Letters, 28(17), 2979-2984,2018.

[33] Wu.Wenneng, Qin, Chen, Anqi, Tai, Guangqi, jiang, Guiping,Ouyang, Synthesis and antiviral activity of 2-substituted methylthio-5-(4-amino2-methylpyrimidin-5-yl)-1,3,4-oxadiazole derivatives. Bioorganic \& Medicinal Chemistry Letters.vol.25,pp.2243-2246,2015.

[34] Wessam , M.S . Abdrabo (2018) . Development of metals GFP analogous :A Gateway for New Biomarker and Photosensitizing Drugs. M.Sc , Chemistry, Dept., Faculty of Science, Benha Univ., Egypt pp 117 
[35] Y.Yang, , D.F.Klessig, Isolation and characterization of a tobacco mosaic virusinducible myb- oncogene homolog from tobacco, Proceedings of the National Academy of Sciences.vol.93,pp.14972-14977,1996.

[36] J. Zhang, B. Zhan, X.Yao, Y.Gao, J.Shong, Antiviral activity of tannin from the pericarp of Punica granatum L. against genital herpes virus invitro. Zhongguo Zhong Yao Za Zhi,vol.55,pp.658-576,1995. 